\title{
ADMINISTRASI PESERTA DIDIK DI SEKOLAH MENENGAH KEJURUAN
}

\author{
Agry Berlianda Putri \\ Pendidikan Teknik Elektro, Fakultas Teknik, Universitas Negeri Padang 2019 \\ Email: agryberliandaputri99@gmail.com
}

\begin{abstract}
Abstrak - Penulisan artikel ini bertujuan untuk membahas tentang administrasi peserta didik di Sekolah Menengah Kejuruan (SMK) mulai dari perencanaan penerimaan peserta didik baru, pembinaan selama di sekolah, sampai dengan menamatkan pendidikan peserta didik tersebut. Administrasi pendidikan adalah proses pengelolaan agar seluruh potensi sekolah berfungsi secara optimal dalam mendukung tercapainya tujuan sekolah. Peserta didik adalah individu yang mengalami perubahan, perkembangan sehingga masih memerlukan bimbingan dan arahan dalam membentuk kepribadian serta sebagai bagian dari struktural proses pendidikan. Dalam Undangundang Sistem Pendidikan Nasional No. 20 tahun 2003 dinyatakan bahwa pendidikan kejuruan adalah pendidikan menengah yang mempersiapkan peserta didik terutama untuk bekerja dalam bidang tertentu.
\end{abstract}

Kata kunci: Administrasi, Peserta Didik, Sekolah Menengah Kejuruan

\section{LATAR BELAKANG}

Sekolah Menengah Kejuruan (SMK) merupakan salah satu jenjang pendidikan menengah dengan kekhususan mempersiapkan lulusannya untuk siap bekerja. Selain fokus kepada mata pelajaran adaptif dan normatif, sekolah menengah kejuruan juga fokus kepada mata pelajaran produktif sesuai kompetensi yang diminati oleh peserta didik. Sehingga diharapkan peserta didik nantinya mengusai setiap kompetensi-kompetensi yang diharapkan oleh dunia usaha atau dunia industri, dan dapat bekerja pada bidang pekerjaan tertentu sesuai dengan bidang keahlian yang ditekuni. Maka sekolah menengah kejuruan sebagai sub sistem pendidikan nasional harus mengutamakan proses pengelolaan peserta didiknya untuk mampu memilih karir, memasuki lapangan kerja, berkompetisi, dan mengembangkan dirinya dengan sukses di lapangan kerja yang cepat berubah dan berkembang seiring berjalan waktu.

Menurut Undang-Undang Dasar Negara Republik Indonesia Tahun 1945 pasal 31 ayat (1) menyebutkan bahwa setiap warga negara berhak mendapat pendidikan, dan menurut UndangUndang Republik Indonesia Nomor 20 Tahun 2003 tentang Sistem Pendidikan Nasional pada Bab 1, pasal 1, dan ayat (1) dijelaskan bahwa:

Pendidikan adalah usaha sadar dan terencana untuk mewujudkan suasana belajar dan proses pembelajaran agar peserta didik secara aktif mengembangkan potensi dirinya untuk memiliki kekuatan spiritual keagamaan, pengendalian diri, kepribadian, kecerdasan, akhlak mulia, serta keterampilan yang diperlukan dirinya, masyarakat, bangsa, dan negara. 


\section{METODE PENELITIAN}

Dalam artikel ini, peneliti menggunakan metode studi literatur dengan mengumpulkan literatur yang bersumber dari buku, jurnal, dan sumber lainnya terkait dengan ilmu Administrasi Pendidikan. Sumber-sumber yang terkait adalah mengenai pengertian administrasi,arti penting administrasi peserta didik,cara mengelola administrasi peserta didik, tujuan administrasi peserta didik dancara menerapkan administrasi peserta didik.

\section{PEMBAHASAN}

\section{A. Definisi}

Administrasi pendidikan adalah proses pengelolaan agar seluruh potensi sekolah berfungsi secara optimal dalam mendukung tercapainya tujuan sekolah. Pengaturan yang dilakukan yaitu mulai dari kegiatan perencanaan, pengorganisasian, pelaksanaan, dan evaluasi. Rangkaian pengaturan tersebut diterapkan pada semua bidang garapan manajemen sekolah. Pengelolaan sekolah meliputi beberapa bidang garapan, yaitu administrasi kurikulum, administrasi peserta didik, administrasi pendidik dan tenaga kependidikan, administrasi sarana dan prasarana pendidikan, administrasi tata usaha sekolah, administrasi pembiayaan, hingga administrasi layanan khusus

Pada.artikel ini, kita akan membahas mengenai administrasi peserta didik di Sekolah Menengah Kejuruan, yang mana peserta didik definisinya secara etimologi adalah anak yang mendapat pengajaran ilmu. Secara terminologi peserta didik adalah anak didik atau individu yang mengalami perubahan, perkembangan sehingga masih memerlukan bimbingan dan arahan dalam membentuk kepribadian serta sebagai bagian dari struktural proses pendidikan. Dengan kata lain peserta didik adalah seorang individu yang tengah mengalami fase perkembangan atau pertumbuhan baik dari segi fisik dan mental maupun fikiran.

Menurut Undang-Undang No. 20 Tahun 2003 peserta didik adalah anggota masyarakat yang berusaha mengembangkan potensi diri melalui proses pembelajaran yang tersedia pada jalur, jenjang, dan jenis pendidikan tertentu.

Menurut Toto Suharto (2006: 123) "Peserta didik adalah makhluk Allah yang terdiri dari aspek jasmani dan rohani yang belum tercapai taraf kematangan, baik fisik, mental, intelektual, maupun psikologinya. Oleh karena itu ia senantiasa memerlukan bantuan, bimbingan dan arahan pendidik untuk dapat mengembangkan potensinya secara optimal dan membimbingnya menuju kedewasaan".

Dapat disimpulkan bahwa administrasi peserta didik adalah suatu proses pengelolaan terhadap peserta didik, meliputi aspek yang luas agar tercapai tujuan pendidikan secara efektif dan efesien.

Pada mekolah menengah kejuruan selain fokus kepada mata pelajaran adaptif dan normatif, sekolah menengah kejuruan juga fokus kepada mata pelajaran produktif sesuai kompetensi yang diminati oleh peserta didik. Sehingga diharapkan peserta didik nantinya mengusai setiap kompetensi-kompetensi yang diharapkan oleh dunia usaha atau dunia industri, dan dapat bekerja pada bidang pekerjaan tertentu sesuai dengan bidang keahlian yang ditekuni. 


\section{B. Tujuan Administrasi Peserta Didik}

Tujuan dari dilaksanakannya administrasi pesertadidik adalah sebagai salah satu cara memaksimalkan proses pembelajaran yang berlangsung dan membantu dari semua sektor pendidikan agartercapainya tujuan dan mutu yang tinggi. Sedangkan tujuan secara khusus adalah membantu peserta didik dalam pembelajaran dan mengatur peserta didki dalam menuntut ilmu di sekolah serta data data pesert didik dapat di simpan dengan baik agardata tersebut tidak hilang dan dapat mempermudah peserta didik dalam mencapai citacita nya dengan sara dan prasarana yang ada di sekolahdi pergunakan semaksimal mungkin.

Menurut McKnow (dalam Asnawir, (2005:168) tujuan administrasi peserta didik, yaitu:

1. Menananamkan kepada peserta didik bagaimana aturan aturan dan pengelolaan sekolah dapat berjalan lancar itu dikarenakan adanya administrasi yang menjadikan peserta didik berjiwa bijaksana dalam berperilaku.

2. Membantu peserta didik dalam mengembangkan dan membangun bakat bakat yang ada di dalam diri peserta didik agar dapat tersalurkan.

3. Membantu peserta didik berkreasi dan berimajinasi dalam melahirkan karya karyanya dan memberikan pemikiran yang kreatif (Afriansyah, 2019).

4. Membantu peserta didik dalam berupaya berfikir postif tentang sifat sifat manusia dan dapat menegelola bagaimana cara bersikap.

5. Menuntun peserta didik dalam mengembangkan upaya dalam meneruskan bakat bakat didalam didirinya.

6. Membantu peserta didik dalam membangun jiwa jiwa menolong dan berkerjasama guna mencapai tujuan bersikap yang layak dengan aturan norma.

7. Membantu peserta didik menumbuhkan jiwa jiwa aktivis yang ingin aktifdan kreatifdalam melakukan kegiatan di sekolah serta dapat menerapkan di luar karangan sekolah (Mulyasa, 2006).

\section{Proses Administrasi Peserta Didik}

Dalam proses administrasi peserta didik, pengelolaan yang dilakukan yaitu mulai dari kegiatan perencanaan, pengorganisasian, pelaksanaan, dan evaluasi. Berikut proses administrasi peserta didik:

1. Perencanaan

a. Menetapkan Daya Tampung

\section{Keterangan:}

DYT = Daya Tampung

$\mathrm{BB}=$ Banyak Bangku

$\mathrm{MB}=$ Muatan Bangku

ATK = Anak Tinggal Kelas 
b. Menentukan syarat-syarat penerimaan peserta didik baru dan membentuk panitia penerimaan peserta didik baru yang ada di sekolah dengan aturan kuota sekolah masing masing. Adapun kegiatan yang dilakukan adalah:

- Melakukian kegiatan publikasi,

- Merancang dan menyediakan formulir pendaftaran

- Melayani proses pendaftaran

- Melaksanakan seleksi

- Mengumumkan calon siswa yang diterima

- Menyiapkan laporan pertanggung jawaban

2. Pelaksanaan

Proses pelaksanaan, yang dapat dilakukan kepada peserta didik adalah sebagai berikut:

a. Mengenalkan kehidupan sekolah baru kepada peserta didik baru

b. Melandaskan karakter dan sikap yang tepat dalam sekolah baru

c. Memperkenalkan fasilitas sekolah baru

d. Memperkenalkan aktivitas akademik dan non akademik

e. Memperkenalkan program sekolah di awal pembelajaran

f. Pengaturan disiplin dan tata tertib sekolah

g. Pengelompokkan peserta didik berkaitan dengan jurusan dan prestasi

h. Pengelolaan di kelas

i. Pencatatan data peserta didik, berupa:

- Buku Induk

Buku induk yaitu suatu buku yang merangkum semua kegiatan peserta didik mulai dari masuk sekolah hingga tamat serta merangkum semua kegiatan yang ada di sekolah termasuk kedalamnya sarana dan prasarana sekolah.

- Buku Keadaan Peserta Didik

Buku ini digunakan dan di berlakukan mulai siswa memulai pelajaran di sekolah tersebut hingga siswa tersebut tamat dari sekolah tetsebut, maka buku tersebut tidak di gunakan lagi.

- Buku Absen Peserta Didik

- Buku Mutasi Peserta Didik

3. Evaluasi

Salah satu bentuk evaluasi yang dapat dilakukan pada proses administrasi peserta didik adalah dengan diadakannya ujian untuk setiap mata pelajaran yang telah diberikan oleh guruguru di sekolah. Apabila peserta didik telah menamatkan (selesai dan lulus) semua mata pelajaran atau kurikulum sekolah, maka peserta didik berhak mendapatkan surat tanda tamat belajar dari kepala sekolah. Dalam hal yang demikian peserta didik sudah tidak mempunyai hak lagi untuk tetap "tinggal" di sekolah yang bersangkutan karena dianggap telah mampu menguasai semua mata pelajaran atau kurikulum sekolah. 


\section{Peran Guru dalam Administrasi Peserta Didik}

Dalam pengelolaan murid guru lebih banyak berperan tidak langsung dibandingkan dengan kepala sekolah yang memegang pucuk pimpinan dalam pengelolaan.

Diantara peranan guru dalam pengelolaan peserta didik adalah:

a. Guru dapat dilibatkan dalam penerimaan peserta didik baru, dengan menunjuk mereka sebagai panitia penerimaan yang dapat melaksanakan tugas-tugas teknis mulai dari pencatatan penerimaan sampai dengan pelaporan pelaksanaan tugas.

b. Peranan yang besar dalam masa orientasi dipegang oleh guru kelas satu, disamping kepala sekolah. Tugas guru adalah membuat murid dapat lebih cepat beradaptasi dengan lingkungan sekolah. Peranan guru dalam hal ini sangat penting, karena kekeliruan dalam orientasi dapat berakibat kurang menguntungkan bagi jiwa anak pada waktu-waktu selanjutnya.

c. Untuk pengaturan kehadiran murid di kelas, guru pun mempunyai andil yang besar.

d. Guru harus mampu menciptakan suasana yang mendorong timbulnya motivasi murid untuk senantiasa berprestasi tinggi.

e. Guru juga harus berperanan besar dalam menciptakan disiplin sekolah atau kelas yang baik, karena di sekolah merupakan masa pembentukan disiplin yang sangat menentukan untuk masa selanjutnya. Untuk membuat murid disiplin, guru diharapkan mampu menjadi contoh atau panutan bagi murid-muridnya.

Adapun menurut (Sutisna,1991), peran guru dalam administrasi peserta didik adalah:

a. Mendatadan Menyeleksi siswa baru.

b. Melaksanakan dan Menyelengarakan pembelajaran.

c. Mengatur dan Mengontrol kehadiran siswa.

d. Melakukan dan meerapkan uji kompetensi akademik/ kejuruan.

e. Membantu dan Melaksanakan bimbingan karier serta penelusuran lulusan peserta didik (Suryosubroto, 2004). 


\section{KESIMPULAN}

Administrasi peserta didik adalah suatu proses mengelola peserta didik untuk tujuan menata dan mengatur peserta didik di sekolah agar tercapainya suatu kegiatan yang sesuai dengan kurikulum. Penting dillakukan administrasi dan tujuan adanya administrasi peserta didik dalam pendidikan adalah untuk mengatur semua kegiatan yang berkaitan peserta didik agar proses belajar mengajar berjalan secara efektif dan efisien sehingga tujuan pendidikan dapat tercapai dengan maksima. Pengaturan yang dilakukan yaitu mulai dari kegiatan perencanaan, pengorganisasian, pelaksanaan, dan evaluasi. Instrumen dalam administrasi peserta didik adalah buku induk, buku daftar keadaan peserta didik, buku absen peserta didik. Adapun peran guru dalam administrasi peserta didik adalah sebagai panitia penyeleksi penerimaan peserta didik baru, berperan dalam memudahkan peserta didik beradaptasi dengan lingkungan sekolah, mencatat dan mengontrol kehadiran siswa, melakukan uji kompetensi, menciptakan suasana yang menimbulkan motivasi siswa, menciptakan disiplin sekolah / kelas yang baik, dan melaksanakan bimbingan karir serta penelusuran lulusan.

\section{DAFTAR PUSTAKA}

1. Afriansyah, H. (2019b). Administrasi Peserta Didik. Padang, Indonesia.

2. Suryosubroto. (2004). Manajemen Pendidikan Di Sekolah. Jakarta: Rineka Cipta.

3. Mulyasa. (2006). Manajemen Berabsis Sekolah. Bandung: PT. Remaja Rosdakarya. 